\title{
RE-PROMOTING AUTONOMOUS LEARNING FOR UNIVERSITY STUDENTS: A LESSON FROM PANDEMIC COVID-19
}

\author{
Girindra Putri Ardana Reswari ${ }^{1 *}$, James Kalimanzila ${ }^{2}$, \\ ${ }^{1}$ Lecturer at Vocational School, Diponegoro University, Tembalang - 50275, Semarang, Indonesia. \\ ${ }^{2}$ Post Graduate School, Airlangga University, 4-6 Airlangga Rd., 60286 Surabaya, Indonesia. \\ Corresponding author's email: girindra.reswari@live.undip.ac.id
}

\section{Article History}

Received : March $08^{\text {th }}, 2021$

Revised : March $17^{\text {th }}, 2021$

Accepted : April 05 ${ }^{\text {th }}, 2021$

Published : May 09 ${ }^{\text {th }}, 2021$

\begin{abstract}
Autonomous learning shifts the focus from teaching to learning in relation to lifelong learning skills. This system helps students to get direct skills and knowledge from different sources rather than focusing on passing their examinations. However, lecturers remain as an advisor and guider. This paper describes the application of autonomous learning and why it is essential to be promoted massively again especially during and after the COVID-19 issue. This study aims to re-promote the practice of autonomous learning as an alternative strategy in learning system due to social distance policy resulted from pandemic covid-19 era. This research has used qualitative research method, both primary and secondary information were collected from various sources such as observation, reading published articles, newspapers, books, social media, universities reports and students' forums, as well as document analysis on the previous research of autonomous learning. Results of the research shows that autonomous learning is a best alternative learning strategic in this tragedy pandemic covid-19 era. However, in order to facilitate and enable this learning student's readiness is more important, this is because it is a selflearning approach. As the conclusion and suggestion, the development of digital service and online studies have increased and stimulated the use of this system.
\end{abstract}

Key words: University Students; Readiness; Autonomous Learning; RePromoting; Covid-19

\section{INTRODUCTION}

According to Richards (2012): Learner autonomy relates to a principle that learners should deal with an increasing their responsibility upon what they learn and how they learn it. Autonomous learning is said to make learning more personal and focused and, consequently, is said to achieve better learning outcomes, since learning is based on learners' needs and preferences. It contrasts with the traditional teacher-led approach in which most decisions are made by the teacher. Concept of autonomous learning has gained most of its momentum in recent years, although the term was first used back in 1981 by Frenchman Henri Holec, largely regarded as the 'father' of learner autonomy.

Autonomous learning shifts the focus from teaching to learning. It does not mean that the teacher becomes redundant, abdicating their control over the learning process, but it does mean the student makes decisions about what and how they learn. The teacher's role is to provide support, encouragement and advice or knowledge when asked. They help the student accomplish things the student themselves wants to achieve. It changes the relationship between students and teachers because the teacher becomes a useful resource in helping them to achieve their goals, rather than somebody who is going to lecture, judge and test them.

Moreover, there are five principles for achieving autonomous learning: Active involvement in student learning, providing options and resources, Offering choices and decision-making opportunities, supporting learners, Encouraging reflection Covid-19 have brought many challenges in learning system. In this pandemic era online learning and digital system have become more useful in self-learning due to social distance resulted from Covid-19. However, there are different style of learning of each student, internet network which then lead to 
the question of whether the learning is still effective.

Furthermore, many learning sources and learning alternative as supplementary materials can be found by students without lecturer's supervision and directives. In covid-19 era, students are supposed to find other alternative learning particularly through digital services as a new strategic rather than depending only lecturer's supplementary material and notes.

Likewise, university student's ages still more actives and fresh, therefore it is more easily to them to use well and utilize their time basing of their readiness particularly in the era 4.0. Many youths are active on and ready on using digital platform, also a lot of learning platform in this digital and social media era. Therefore, this research will re-promote again the autonomous learning that is very suitable to be adapt to COVID-19 emergency in order to help students to improve their skills and knowledge.

Furthermore, this research will base focus on answering the following questions in collecting and analyzing its data: -

$>$ How was the implementation of Autonomous Learning in higher education students before COVID-19?

$>$ Why COVID-19 is suitable to be repromoting during pandemic?

$>$ Can autonomous learning be a solution in higher education to the problems of education in COVID-19 era?

\section{METHOD}

This research is a qualitative research. According to Cohen (2013) qualitative study has an orientation to social context, and the participants usually focus on human subjectivity. Related to the data collection, observation is being used in order to learn about the phenomena during the COVID-19 in terms of higher education learning system.

The observation is supported by the interview of higher education students and lecturers. Mack et al (2005) explained that an interview is a technique designed to real picturization of what is happened during the setting of the study. The information collected by this instrument helped the researchers to crossexamine some key issues in the research.

The data collection also being supported by document analysis methods that is done by collecting data from social media, publications, articles, book, and news broadcasting. According to Bowen (2009) document analysis is a systematic procedure to review or evaluate document that can be taken from both printed and electronic materials.

Narrowing the method to the use of social media as document analysis methods, Lai $\&$ to (2015) found that social media is very suitable to be a part of document study for supporting a research. It is because social media have already become the most essential part that cannot be separated with human life because it succeeds to affects all elements of human life such as the beliefs, values, and attitudes of people, as well as their intentions and behaviors.

\section{RESULT AND DISCUSSION}

\section{Theories on Autonomous Learning}

Shakouri and Jooneghani (2012) stated that the term autonomy has become controversy among the linguists and educationalists. There is a debate to reach a consensus on what autonomy really is. In language learning context, autonomy is correlated to desirable goal for philosophical, pedagogical, and practical reasons. As Holec (1981) illustrates autonomy as "the ability to take charge of one's learning", many practitioners still not consider autonomous learning as teachingless learning, but more to the synonym of selfaccess and especially with technology-based learning.

Autonomous learning also often associated with self-directed learning as mentioned in Ponton (1999) who defined learner autonomy as the characteristic of the person who independently exhibits agency in learning activities and stated that autonomy represents a subset of the attributes associated with selfdirectedness. According to Candy (1995) and Silen and Uhlin (2008) self-directed learning is also similar with self-study in which the students is on/ his own and does not bother anyone. It is in line with Silen (2006) who mentioned that there are two factors that are very essential in the process of SDL development: 1) The students' feelings of being in charge and having a genuine impact on the learning situations are crucial for their desire to take responsibility; 2) Feelings of being in charge are connected to understanding the demands of the learning context, experiences of managing and getting feedback. 
Related to the responsibility of students as the self-directed learning or autonomous learning, Pierson (1996) and Seong et al., (2015) stated that autonomous learning has fundamental principle in which the control and responsibility lies primarily in the hands of the individual learner. They should have a personal agenda for learning which include all the set-up directions such as planning, pacing, monitoring, and evaluation of the learning process.

The concepts of learner autonomy and self-directed learning then could not be separated from self-determination theory which provided a theoretical rationale for the action program for learner autonomy. SDT is an approach to human motivation and personality integration, as well as the supported condition that help the positive processes happened. It is a theory of motivation which has relation to some aspects such as autonomy, competence, and relatedness to selfdetermined motivation and self-regulated behavior (Ryan and Deci, 2010). It is in line with Núñez and León (2015) who mentioned that motivation is the engine of long-term task persistence as needed by autonomous learning implementation.

\section{The Education Phenomena during COVID-19}

According to Hannahan (2020) education system worldwide has been affected and forced more than 1.5 billion students out of school and universities. COVID-19 is affecting all aspects of human life, including education system. It is causing the total closure of schools and universities impacting students worldwide. According World Bank (2020) reports around March 25 over one billion students all over the world were affected by the school closure due to COVID-19. School closure came as an anticipation as well as supporting the social distancing regulation to slow down the spread of the COVID-19.

In order to keep the education running, a new trend of education is now forced to be done. It is called "online learning". UNESCO (2020) put "Distance Learning Solutions" in their website. It is contained of some lists of important links to go to online learning supports such as Digital learning management systems for example: ClassDojo, Edmodo, Google Classroom, and many more. Other information given are some links about: Systems built for use on basic mobile phones, Systems with strong offline functionality, Massive Open Online Course (MOOC) Platforms, and etc.
Similar with UNESCO, most of the schools in the world are dealing with COVID-19 situation by using virtual class or online learning. However, it is found that not all studies support this teaching method. They found some drawbacks of online learning methods. Sintema (2020) mentioned that different studies have shown that although there are some examples of having a plan of using the distance/online learning during the pandemic, they are mostly concentrated on small cases and not a global crisis as it is happening in COVID-19 pandemic of 2020. Especially the countries that are having the limited technologies have problems in schools are not ready for the complete implementation of the countrywide online education.

It is supported by the data coming from ASEAN regions. Data reported by done by Kemp (2019) and ASEAN Statistical Report on Millennium Development Goals 2017 South East Asia which is dominated by developing countries was reached 63 of the population that do not have access to the Internet and electronic devices. It can be stated that there is a gap among the societies in each country in South East Asia in accessing the internet. There are only three countries that has reached $80 \%$ active internet users from total population. Those are Singapore, Brunei, and Malaysia. Other countries such as Indonesia, Thailand, Myanmar, and Vietnam only have less than $60 \%$ internet penetration.

In other side, some countries are started to reopen their schools since May until now. The discussions upon it is safe to reopen the schools are still debatable. However, some countries such as French, South Korea, and Finland then decided to reopen the schools under some circumstances. As what happened in French, Domenico et al., (2020) stated that French authorities will gradually open the school with some specific protocols. Pre-schools and primary schools are expected to reopen under the consideration that classes will be limited to groups of 15 and attendance will be on a voluntary basis. Middle schools may follow one week later, but only in those departments weakly affected by the epidemic. Middle school students will be asked to wear masks, differently from younger children. Reopening of high schools will be decided in late May, depending on the epidemic evolution. However, Universities will remain closed till next academic year.

Autonomous Learning in Previous Researches 
Autonomous learning is not a new thing in the education world. A lot of researches have been done since many years ago related to the implement Autonomous Learning to support students' success in education. However, most of the research is related to language learning especially English Language and English as Foreign Language. According to Najeeb (2013) learning foreign language is much related to autonomous learning because it needs an interactive and social process. Autonomous learners can freely choose and apply their knowledge and skills outside the immediate learning context.

The correlation of the interdependency between autonomous learning and learning foreign language is also explained by Üstünlüoğlu (2009). In the case of English learner from other languages, many researches already done many and multiple researches to investigate the lack of the English proficiency levels for university students which are not sufficient in spite of the efforts of instructors and students. The Common European Framework (Council of Europe 2001, CEF) defines the concept of language learning autonomy as consisting of both those items which need to be learned in order for adequate communication, and the knowledge and skills which need to be developed by an effective autonomous learner.

The question which is following the discussions then can autonomous learning be used to other subjects rather than language? Even if the publications related to it are not as many as the language ones, in fact many subjects are also used autonomous learning for their approach to support students' mastery in education. Linneweber-Lammerskitten et al., (2010) conducted a research related to the use of visual technology for the autonomous learning of Mathematics. This research describes a collaborative research and development project between the University of Applied Sciences Northwestern Switzerland and Rhodes University in South Africa. The project seeks to establish, disseminate and research the efficacy and use of short video clips designed specifically for the autonomous learning of mathematics.

Another example of other subject that also had autonomous learning as their research practice is conducted by JI Huang-feng et al., (2007). The research is about nursing students' autonomous learning ability in different stages. This research is conducted to understand the ability of professional nursing students at the two stages of practicing their second stages at medical school.

After looking for the researches related to other subjects that also used autonomous learning, it could be concluded that the autonomous learning researches are dominated by English and other Language Learning focus. It is very difficult to find the studies about the use of autonomous learning for other subjects.

\section{Autonomous Learning Approach for All Subjects in Higher Education}

Introducing students to do autonomous learning for all subjects are considered important. Allwright (1990) stated that autonomous learners can be seen as those who are able to reflect on their own learning and who are willing to learn in collaboration with others. Autonomous learning is about being responsible of what they should learn to improve their own knowledge and skills (üstünlüoğlu, 2009). In line with that, Najeeb (2013) explained that by doing autonomous learning means that these learners understand the purpose of their learning program, explicitly accept responsibility for their learning, share in the setting of learning goals, take initiatives in planning and executing learning activities, and regularly review their learning and evaluate its effectiveness. In other words, there is a consensus that the practice of learner autonomy requires insight, a positive attitude, a capacity for reflection, and a readiness to be proactive in self-management and in interaction with others.

In relation to that, Reindars (2010) explained that since 1950s, influenced by the work of George Kelly (c.f. Kelly, 1955) and others in psychology, active individual who brings previous experiences, beliefs and preferences to the classroom is better compare to see the learner as a passive container to be filled with the teacher's ideas. These can be seen as humanist approaches considered the learner as someone who actively shapes his or her learning experiences with the purpose of selfdevelopment and fulfilment.

Richard (2012) stated that autonomous learning is all life learning, never ending progression. Supported by Candy (1991) who states that "learner autonomy is a constant process open to educational interventions, rather than a state, which is reached once and for all." Self-directed learning is seen to be crucial to the attainment of lifelong learning to meet the fastchanging needs of the global world, where 
individuals assume responsibility in maintaining the currency of their knowledge and skills (Richards and Smith, 2006). It means that ready or not, students should have an understanding about their learning responsibility and the concept of autonomous learning since they will use it until they are growing to other steps of life.

Since autonomous learning involve big responsibility, it is important to see the capability of students in such motivation. Thus why, autonomous learning usually being used by students in university level. Channock et al. (2004) stated that The UK Quality Assurance Agency for Higher Education as does the Australian government among others already included independent learning or autonomous learning as graduate attributes. It is supported by Macaskill and Denovan (2013) by explained that the success of autonomous learning is related to character strengths which were shown significantly associated with the measures of selfefficacy at university, self-esteem, and autonomous learning in ways that theoretically made sense. The character strengths underpin the generation of positive cognitions, emotions and motivation, all of which are necessary for the development of autonomous learning.

From the initial assessment of strengths, autonomous learning was predicted by hope agency and exploratory curiosity, accounting for a reasonable amount of variance. Moreover, according to Field, Duffy, and Huggins (2015) independent learning skills are one of the keys of success for every student in higher education. SAM et al., (2012) supported this finding by stated that autonomous learning is not only helping student for their study, but also for their future career.

\section{University Students' Readiness in Implementing Autonomous Learning}

Even if autonomous learning has been promoting since many years ago and the subjects of those previous studies are various, one thing that is linier is the result of those studies. Many researches including all previous researches mentioned above found that students' capability in doing autonomous learning is various. Some students can do that completely based on themselves, but some others need the guidance and support for their instructors, teachers, peers, and environment. Therefore, it could not be stated directly that autonomous learning have already succeed, yet; re-analyse and re-promote the practice of autonomous learning are needed to be done.

That is why even if it is called learning by autonomy, the role of lecturer is so important in achieving learning success. Lecturer must share the responsibility for contributing to the development of strategies and approaches that support the well-being of university students, and the curriculum provides an important opportunity to do this (Krieger, 2011). Indeed the curriculum is a critical site for the creation of learning and teaching environments that not only address the high levels of psychological distress, but also promote student well-being, by empowering and enabling students. The good motivation will create a positive psychology for the students which will create focus to the students in doing their autonomy learning (Huggins, 2012; Peterson \& Schreiber, 2006).

Autonomous learning still needs teacherlearner relationship. It does not mean that the teachers are doing nothing. The difference is learner and teacher role will move from the traditional into modern one. Students will no longer depend to the lecturer and see the lecturer as an expert. Learners will get responsibility for planning, implementing, and evaluation the outcomes of the learning. They will get both the supportive framework of teacher-learner and peer relationship (Brew \& Boud, 1988). Other researchers such as Boud and Higgs (2013) emphasis the need of teacher in autonomous learning as manager, resource person, designers, and producers for helping learners acquire he content and only secondarily as content resources.

Among others, the most important role of teachers in this autonomous learning approach is to motivate the students. Thanasoulas (2000) stated that it is the teacher's role to maintain a learning environment in order to maintain a learning environment for the students. McCombs (2010) mentioned that these learner-centered practices include teachers showing students how to make learning choices and monitor the positive and negative consequences of their choices. This is a trial-and-error process that requires teacher support, modeling and encouragement. To productively create the good cooperation between teacher and student, Nguyen (2012) suggested the teachers to see each student as someone valuable and worth. As a result, students will feel motivated because this will help them to discover their own experiences, and learning is seen as being related to their own 
needs. Moreover, teachers are able to assist students in the decision-making process as instructors, guides and facilitators (Kesten, 1987).

\section{Autonomous Learning and COVID-19}

The theory of different learning styles of students might answer the question on why it is not easy to make all students succeed in doing the learning activity during COVID-19. Dunn (1990) learning style model identified five main stimuli that trigger the different learning motivation. Those are environmental, emotional, sociological, physical and psychological factors.

Grasha (1996) explained about six different learning styles based on modes of student behaviour in learning environment at the university level as follows: 1) Independent learning style - the learning style of students who prefer to get the guidance from instructors as minim as it can. They love to work alone and prefer to learn the content that they think is necessary for them. In the classroom, they like self-paced instruction and independent-task assignments. 2) Avoidant learning style - the learning style of students with a high rate of absenteeism. Usually they have poor work and study habits. They prefer to remain quiet in the class and not get much attention to prevent getting called by the instructor. 3) Dependent learning style - the learning style of students who are really depend on the lecturer and friends to complete their learning tasks. This kind of students will always look for the clearest guidance and guidelines as their instructions. They also prefer to get notes from lecturer or friends to complete their own notes. 4) Collaborative learning style - the learning style of students who love to work in a group. They like to have interactions while study or work. They will prefer group activity such as discussion and group projects. In short, they feel that they can learn maximumly by sharing ideas and knowledge. 5) Participative learning style - the learning style of students who are attentive and responsive to coursework requirement.

These students are always be an active students in the class and usually called as "good students" in class, eager to submit the task on time, and being so confident in the class. 6) Competitive learning style - this learning style usually showed by students that really like to proof that they are better than others or even the best. They will always emphasis high grades and attention from lecturer. They might need rewards or recognition upon their study results.

Those different learning styles actually create a problem for the implementation of learning during this COVID-19. It is because the learning process then cannot mix the learning situation to accommodate all learning styles of the students. Another problem is the learning method that is used during this pandemic is always related to technology as what is explained in the above discussion, many troubles related to the limited access to the internet is still happened. As the result, students cannot achieved the learning results equal to when they do in the normal one. It is worsen by the students' psychological condition. The stress from the students came from the fact that the school closure is indefinite as nobody knows when the cure or the vaccine for the COVID-19 is going to be found. During this COVID-19 several severe issues impacted a lot to the society such as psychological distress and depression including perception of safety, risk and threat of contagion, quarantine, stigma and social exclusion, and the worst scenario which are financial loss and job insecurity (Alradhawi, et al., 2020).

It is therefore, re-promoting autonomous learning for students could be the best solution for students to keep learning and get their knowledge by doing something that they like. As stated by Zimmerman (1986) that autonomous learners have the following three key characteristics: understanding of their own approach to learning and how best to efficiently maximise their learning; motivation to take responsibility for their learning; and ability to work with others to enhance the depth and breadth of their learning.

Instead of giving more project and homework that make students stress, students can maximise their learning by choosing their own learning activity based on their learning style. As what In Indonesia, many protests happened on the point of too much task without getting insight and knowledge from their class as we can see the news in many big local news media such as thejakartapost, tirto.id, and kompas.

Student's enthusiasm in learning is actually there. Every webinar is full of viewers, every live streaming in various platforms such as Youtube live, Instagram live, Facebook live, Zoom live, TikTok live, and many more are always full of viewers. Webinars are becoming the new trends. We can see many webinars happened in one day. Jordan (2020) in her blog 
explained that social media trends continue to change as do the ways in which students interact with their initiatives. The results of her interviews showed that students are choosing TikTok and Instagram Live because those platforms providing new ways for them to interact with one another and the world around them.

Related to be the content will be useful for the learner's need of knowledge, right now many platforms are already full with useful information that suitable for the long live learning as the goal of the online learning. It is then just needed the help from the teachers as guidance as what been stated before. World Economic Forum (2020) mentioned that some school districts are forming unique partnerships, like the one between The Los Angeles Unified School District and PBS SoCal/KCET to offer local educational broadcasts, with separate channels focused on different ages, and a range of digital options. Media organizations such as the BBC are also powering virtual learning; Bitesize Daily, launched on 20 April, is offering 14 weeks of curriculum-based learning for kids across the UK with celebrities like Manchester City footballer Sergio Aguero teaching some of the content.

This re-promotion of autonomous learning for higher education students also will help the students that get the burden from the online learning in term of economical and electronical reason. Retrieved from UN News (2020) UNESCO Director General, Audrey Azoulay stated that the support to other alternatives including the use of community radio and television broadcasts, and creativity in all ways of learning must be increased to lower the inequalities of education. Education should provide all hi-tech, low-tech, and no-tech approaches based on the need of the students.

By enhancing the autonomous learning for students in higher education, at least student can choose and use their online platform that based on their capacity, aside from their obligatory media and learning style from their educational institution. It will also help them to learn based on their learning style. Whether they want to do their autonomous learning in groups, individual, or learn from others.

\section{CONCLUSION}

Autonomous learning is not a phenomenon in its relation to higher education. However, the implementation is still dominated by Foreign Language Learning. The implementation even still not maximum. It is because students are usually still get the full knowledge from the meeting. During this COVID-19, some challenges related to the transfer of knowledge then happened. The problems are about the online learning platform that cannot be reach by students maximumly. Another problem is the different style of students learning that online learning could not accommodated. It is therefore, autonomous learning should be re-promoted to the higher education students. Higher education students are considered adult enough to take their own decision and being responsible in their own choice of learning. The lecturers also have a big role to support the success of autonomous learning. The task is to manage and motivate the students in doing the activity, but not to force and become the centred of their supplementary learning.

\section{ACKNOWLEDMENT}

Thank you to the authors to all those who have helped so that this paper is completed.

\section{REFERENCES}

Allwright, D. (1990). Autonomy in language pedagogy. CRILE Working Paper, 6.

Alradhawi, M., Shubber, N., Sheppard, J., \& Ali, Y. (2020). Effects of the COVID-19 pandemic on mental well-being amongst individuals in society-A letter to the editor on "The Socio-Economic Implications of the Coronavirus and COVID-19 Pandemic: A Review". International journal of surgery (London, England).

Apinino, R. (2020, March 16). Belajar di Rumah karena Corona COVID-19, Efektifkah? Retrieved June 12, 2020, from https://tirto.id/belajar-di-rumah-karenacorona-covid-19-efektifkah-eFtZ

Boud, D., \& Higgs, J. (2013). Bringing selfdirected learning into the mainstream of tertiary education. In Learner Managed Learning (pp. 166-181). Routledge.

Bowen, G. A. (2009). Document analysis as a qualitative research method. Qualitative research journal, 9(2), 27. 
Brew, A., \& Boud, D. (1995). Teaching and research: Establishing the vital link with learning. Higher education, 29(3), 261273.

Candy, P. C. (1991). Self-Direction for Lifelong Learning. A Comprehensive Guide to Theory and Practice. Jossey-Bass, 350 Sansome Street, San Francisco, CA 941041310.

Chanock, K., Clerehan, R., Moore, T., \& Prince, A. (2004). Shaping University Teaching towards Measurement for Accountability: Problems of the Graduate Skills Assessment Test. Australian Universities' Review, 47(1), 22-29.

Council of Europe. Council for Cultural Cooperation. Education Committee. Modern Languages Division. (2001). Common European Framework of Reference for Languages: learning, teaching, assessment. Cambridge University Press.

Deci, E. L., \& Ryan, R. M. (2010). Selfdetermination. The Corsini encyclopaedia of psychology, 1-2.

Domenico, et al., (2020). Expected impact of lockdown in Ile-de-france and possible exit strategies. medrxiv 2020.04.13.20063933.

Dunn, R. (1990). Understanding the Dunn and Dunn learning styles model and the need for individual diagnosis and prescription. Reading, Writing, and Learning Disabilities, 6(3), 223-247.

Field, R., Duffy, J., \& Huggins, A. (2015). Teaching Independent Learning Skills in the First Year: A Positive Psychology Strategy for Promoting Law Student WellBeing. Journal of Learning Design, 8(2), $1-10$.

Grasha, A. F. (1996). Teaching with style: A practical guide to enhancing learning by understanding teaching and learning styles. Alliance publishers.

Hannahan, P. (2020, April 27). Adapting approaches to deliver quality education in response to COVID-19. Retrieved May 23, 2020 ,

from https://www.brookings.edu/blog/educatio n-plus-development/2020/04/23/adaptingapproaches-to-deliver-quality-educationin-response-to-covid-19/.

Harto, R.B. (2020, May 21) (Transforming Indonesia's education through online learning. Retrieved June 12, 2020, from https://www.thejakartapost.com/academia 12020/05/21/transforming-indonesiaseducation-through-online-learning.html

Holec, H. (1981) Autonomy and Foreign Language Learning. Council of Europe, Oxford: Pergamon Press.

Huggins, A. (2012). Autonomy supportive curriculum design: A salient factor in promoting law students' wellbeing. UnsWlJ, 35, 683.

JI, H. F., GENG, G. L., \& WANG, C. S. (2007). Inquisition of nursing students' autonomous learning ability in different stages [J]. China Higher Medical Education, 9.

Jordan, C. (2020, May 13). How to Utilize TikTok and Instagram Live for Maximum Student Engagement | Blog | Presence. Retrieved June 12, 2020, from https://www.presence.io/blog/how-toutilize-tiktok-and-instagram-live-formaximum-student-engagement/

Kemp, S. (2019). Digital 2019: Indonesia. Retrieved from Datareportal: https://datareportal. com/reports/digital2019-indonesia.

Kesten, C. (1987). Independent Learning: A Common Essential Learning: A Study Completed for the Saskatchewan Department of Education Core Curriculum Investigation Project.

Krieger, K., \& Rösner, D. (2011). Linked data in e-learning: a survey. J. Semant. Web, 1, 19.

Lai, L. S., \& To, W. M. (2015). Content analysis of social media: A grounded theory approach. Journal of Electronic Commerce Research, 16(2), 138. 
Linneweber-Lammerskitten, H., Schafer, M., \& Samson, D. (2010). Visual technology for the autonomous learning of mathematics. Pythagoras, 2010(72), 2735 .

Macaskill, A., \& Denovan, A. (2013). Developing autonomous learning in first year university students using perspectives from positive psychology. Studies in Higher Education, 38(1), 124-142.

Mack, R., Giarelli, E., \& Bernhardt, B. A. (2009). The adolescent research participant: strategies for productive and ethical interviewing. Journal of pediatric nursing, 24(6), 448-457.

McCombs, B. (2010). Developing Responsible and Autonomous Learners: A Key to Motivating Students: Teacher's Modules.

Najeeb, S. S. (2013). Learner autonomy in language learning. Procedia-Social and Behavioral Sciences, 70, 1238-1242.

Núñez, J. L., \& León, J. (2015). Autonomy support in the classroom: A review from self-determination theory. European Psychologist, 20(4), 275.

Peterson, S. E., \& Schreiber, J. B. (2006). An attributional analysis of personal and interpersonal motivation for collaborative projects. Journal of Educational Psychology, 98(4), 777.

Pierson, H. D. (1996). Learner culture and learner autonomy in the Hong Kong Chinese context. Taking control: Autonomy in language learning, 49-58.

Ponton, M. K. (1999). A quasi-linear behavioral model and an application to self-directed learning. National Aeronautics and Space Administration, Langley Research Center.

Reinders, H. (2010). Towards a classroom pedagogy for learner autonomy: A framework of independent language learning skills. Australian Journal of Teacher Education (Online), 35(5), 40.

Richards, D., \& Smith, M. (2006). The tensions of political control and administrative autonomy: from NPM to a reconstituted Westminster model. Autonomy and control: Coping with agencies in the modern state, 181-202.

Richards, J. C. (2012, November 5). Learner autonomy in language teaching. Retrieved June 11, 2020, from https://www.professorjackrichards.com/le arner-autonomy-in-language-teaching/

SAM, C., Vutha, R. O. S., Onn, K. E. O., \& Phearak, S. O. P. H. A. L. Factors Promoting Independent Learning among Foundation Year Students.

Shakouri-Masouleh, N., \& BahraminezhadJooneghani, R. (2012). The secrecy underlying young language learners' learning. World Academy of Science and Technology, 66, 2012.

Silén, C. (2006). The tutor's approach in base groups (PBL). Higher Education, 51(3), 373-385.

Silén, C., \& Uhlin, L. (2008). Self-directed learning-a learning issue for students and faculty!. Teaching in Higher Education, 13(4), 461-475.

Sintema, E. J. (2020). Effect of COVID-19 on the Performance of Grade 12 Students: Implications for STEM Education. Eurasia Journal of Mathematics, Science and Technology Education, 16(7), em1851.

Thanasoulas, D. (2000). Autonomy and learning: An epistemological approach. Applied Semiotics, 10, 115-131.

Üstünlüoğlu, E. (2009). Autonomy in language learning: Do students take responsibility for their learning?. Journal of Theory \& Practice in Education (JTPE), 5(2).

World Bank. (2020). How does COVID19 impact education? Retrieved May 23, 2020 ,

from http://pubdocs.worldbank.org/en/4508815 85235950757/COVID19-EducationSector-Guidance-Note-March26.pdf

Zimmerman, B. J. (1994). Dimensions of academic self-regulation: A conceptual framework for education. Self-regulation 
of learning and performance: Issues and educational applications, 1, 33-21.

Startling disparities in digital learning emerge as COVID-19 spreads: (2020, April 24). Retrieved June 12, 2020, from https://news.un.org/en/story/2020/04/1062 232

Survei: Sistem Belajar Online Membosankan dan Bikin Stres Halaman all - Kompas.com. (2020, April 16). Retrieved June 12, 2020, from

https://surabaya.kompas.com/read/2020/0 4/16/15230481/survei-sistem-belajaronline-membosankan-dan-bikin$\underline{\text { stres?page }=\text { all }}$

The rise of online learning during the COVID-19 pandemic. (2020, April 29). Retrieved June 12, 2020, from https://www.weforum.org/agenda/2020/04 /coronavirus-education-global-covid19online-digital-learning/ 